\title{
PELAYANAN AKADEMIK E-LIBRARY DI UNIVERSITAS MUHAMMADIYAH MAKASSAR
}

\author{
Yusriani $^{1}$, Lukman Hakim ${ }^{2}$, Musliha Karim ${ }^{3}$ \\ ${ }^{1)}$ Mahasiswa, Jurusan Ilmu Administasi Negara Unismuh Makassar \\ 2) Dosen, Jurusan Ilmu Administasi Negara Unismuh Makassar \\ 3) Dosen, Jurusan Ilmu Administasi Negara Unismuh Makassar
}

\begin{abstract}
The objective of this study is to investigate the quality of E-library academic services at Muhammadiyah University of Makassar. The samples of the research consist of 100 respondents. The type of the research is qualitative descriptive with survey research type. The data derive from primary data collected from the students' data by utilizing research instruments such as questionnaires, documents and direct interview towards five informants. The results of the research indicate that E-library academic services at Muhammadiyah University of Makassar have generally been qualified in terms of the five service dimension such as; Reliability,12 (77,91\%)which means in very good category; Responsiveness 3,18 (79,5)means in good category; Assurance 3,10 (55,58\%)means in very good category: Empathy 3,38 (84,62\%)means in very good category; and Tangible 3,19 (79,25\%)means in very good category.
\end{abstract}

Key word : Quality, academic service, E-Library

\begin{abstract}
ABSTRAK
Tujuan penelitian untuk mengetahui bagaimana kualitas pelayanan akademik $E$ library di Universitas Muhammadiyah Makassar. Sampel dalam penelitian ini berjumlah 100 responden. Jenis penelitian ini adalah menggunakan deskriptif kuantitatif, dengan tipe penelitian survey. Jenis data terdiri primer yang di peroleh melalui data mahasiswa dengan menggunakan instrument berupa kuesioner dan dokumentasi dengan wawancara langsung terhadap lima informan. Hash penelitian inimenunjukkan bahwa umumnya pelayanan akademik E-Library Di UniversitasMuhammadiyah Makassar sudah dapat dikatakan baik dalam pelayanan dilihat dari kelima dimensi pelayanan yaitu (Reability)adalah 3,12 (77,91\%) pada kategori sangat baik, Ketanggapan (Responsiveness) 3,18 (79,5) pada kategori baik, (Assurance) 3,10 (55,58\%) pada kategori sangat baik, (Empathy) 3,38 (84,62\%) pada kategori baik dan (Tangible)3,19 (79,25\%)pada kategori sangat baik.
\end{abstract}

Kata Kunci; Kualitas Pelayanan Akademik E-Library 


\section{PENDAHULUAN}

Teknologi dan informasi yang modern seperti saat ini, kebutuhkan masyarakat terhadap informasi dan media edukasi merupakan hal yang penting dan menjadi tantangan tersendiri bagi penyedia jasa informasi dan edukasi yang ada di indonesia. lembaga pendidikan seperti perguruan tinggi negeri yang bergerak di bidang edukasi dan informasi juga tidak luput dari perkembangan teknologi informasi yang cepat dan tuntutan untuk meningkatkan pelayanan di bidang pendidikan. Dalam Undang-Undang RI Nomor 20 Tahun 2003 tentang Sistem Pendidikan Nasional disebutkan bahwa perguruan tinggi merupakan salah satu lembaga penyelenggara pendidikan tinggi yang bertujuan untuk melaksanakan Tri Dharma perguruan tinggi yaitu Pendidikan penelitian dan pengabdiaan masyarakat. untuk mencapai tujuannya, maka perpustakaan perguruan tinggi memiliki peran yang sangat penting melaksanakan ketiga dharma perguruan tinggi tersebut.

Pendidikan memiliki tujuan sebagaimana yang telah ditetapkan dalam Undang-Undang tentang tujuan
Pendidikan nasional (Siswoyo dkk, 2007 :87) adalah untuk berkembangnya potensi peserta didik agar menjadi manusia yang beriman dan bertakwa keada Tuhan Yang Maha Esa, berakhlak mulia, sehat, berilmu, cakap, kreatif, mandiri dan menjadi warga Negara yang demokratis serta bertanggung jawab. Untuk mencapai tujuan Pendidikan nasional tersebut tentu saja harus diikuti peningkatan sumber-sumber penunjang pelaksanaan Pendidikan salah satunya sumber belajar.

Pelayanan yang bagus adalah pelayanan yang dapat memahami nilai lebih pelanggan. Dalam Kamus Besar Bahasa Indonesia (2001:24)” pelayanan adalah usaha melayani orang lain". Dari pengertian tersebut juga dapat diperluas berdasarkan definisi.

Menurut Hasibuan (2007:152), pelayanan adalah kegiatan pemberian jasa dari satu pihak lain dilakukan secara ramah tamah, adil, cepat, tepat dan dengan etika yang baik sehingga memenuhi kebutuhan dan kepuasan bagi yang menerimanya.

Dapat ditarik suatu kesimpulan bahwa pelayanan adalah suatu bentuk kinerja atau upaya untuk melayani 
orang lain/ pelanggan, yang tidak berwujud dan juga tidak bisa dimiiki tetapi bisa dirasakan dan memberikan kepuasan kepada pelanggan pengguna layanan. Konsumen serta berusaha untuk memberikan nilai lebih kepada pelanggan. bukan saja perguruan tinggi negeri tapi perguruan tinggi swasta juga harus berupaya ikut serta meningkatkan kualitas layanan pendidikan meraka, karena kualitas pelayanan pendidikan merupakan usaha yang dapat meningkatkan citra di image konsumen khususnya mahasiswa.

Perpustakaan digital memerlukan perencanaan dan proses manajemen dari suatu organisasi. Teknologi digital dan proses digital adalah faktor penggerak revolusi khusus yang terjadi pada area teknologi informasi terutama dalam perpustakaan dan institut informasi lain. Dengan menggunakan system E-Library banyak penggunanya akan mendapatkan kemudahan dalam mengakses informasi dengan cepat. Perpustakaan digital menjadi semakin terintegrasi karena umumnya dibangun untuk ketersediaan koleksi dan jasa untuk kebutuhan pemakai.Sesuai teori Menurut Wahyu Supriyanto dan
Ahmad Muhsin

(2008:31)

perpustakaan digital adalah sebuah sistem yang memiliki berbagai layanan dan objek informasi yang mendukung akses objek informasi tesebut melalui perangkat digital." Perpustakaan adalah sumber belajar yang memberikan pelayanan informasi dan keterampilan penelusuran informasi bagi pemakainya.

E-library ini sesuai dengan teori manejemen juga harus tertata baik secara administratif, kelengkapan, pengorganisasian dan pelayanan. Manejemen atau pengelolaan $E$ Library pusat itu sendiri akan sangat mempengaruhi minat baca para pengunjungnya, karena minat baca seseorang itu tergantung pada kepuasan yang mereka dapatkan saat berkunjung.

E-Library Universitas Muhammadiyah Makassar merupakan Unit Peklasana Teknis (UPT) yang tidak terlepas keberadaannya dari kegiatan kampus, dimana akan memerankan fungsi fital dalam keberhasilan perkulihan baik bagi mahasiswa, dosen, selain itu pengguna lainnya. Perpustakaan Muhammadiyah Makassar mempunyai enam layanan yaitu: 1. Layanan administari melayani 
hal-hal yang berkaitan dengan buku metode penelitian. Ditambah lagi keanggotaan, 2. Layanan sirkulasi kurangnya buku-buku yang sesuai melayani pemimjaman. 3. dengan jurusan masing-masing fakultas Pengembalian dan perpanjangan buku .Ketidakrapian tata letak referensi, yang di pinjam. 4. Layanan referensi seperti buku-buku. Dan dibuktikan oleh melayani berbagai macam pertanyaan pengguna perpustakaan E-Library yang penulis sendiri disaat mencari data statistik pengunjung sangat susah mengalami kesulitan dalam mendapatkannya, bahkan dipimpong menemukan suatu informasi. 5. pamping. semua penjelasan diatas Layanan audio visual memberikan dapat di simpulkan bahwa fasilitas layanan dalam mengakses informasi komputer dan hot spot merupakan melalui layanan audi visual seperti internet,layanan fotocopy center sarana dan prasarana yang sangat penting dalam sebuah E-Library karena melayani berbagai macam kebutuhan tidak akan berjalan lancar suatu pengguna E-Library dalam hal lembaga perguruan tinggi dan tidak fotocoyp digital, yang terakhir yaitu mencapai tujuan dicanangkan. layanann pengadaan koleksi melayani berbagai usulan pelayanan pengguna perpustakaan yang berhubungan Perngertiann kepuasan pelanggan berarti bahwa kinerja suatu jasa atau barang sekurang-kurangnya sama dengan berbagai macam jenis kolesi perpustakaan. dengan apa yang diharapkan (Supranto, 2006:224). Seperti seorang mahasiswa

Namun pada kenyataannyaa, yang mengharapkan petugas E-Library pelayanan masih ada yang belum memberikan pelayanan dengan baik terlaksana dengan baik seperti : dalam melayanai fotocopy digital masih lambat, komputer masih sangat kurang, Jaringan internet E-Library masih bergantung pada jaringan hos pot sehingga mahasiswa merasa puas di saat berkunjung di E-Library.

Menurut Barata (2010:10) bahwa suatu pelayanan akan terbentuk karena adanya proses pemberian layanan rektorat dan belum ada jaringan hos pot tertentu dari pihak penyedia layanan tersendirinya. Kelengkapan bukukepada pihak yang dilayani buku juga masih kurang seperti buku- 
Menurut Tjiptono (2006:87) pelayanan sebagai tindakan atau perbuatan seseorang atau organisasi untuk memberikan kepuasan kepada pelanggan. Sedangkan Kotler, Amstrong, dkk (2002:220) mendefinisikan pelayanan adalah aktifitas suatu hal yang menguntungkan tetapi merupakan salah satu bagian penting yang di tawarkan dimana sifatnya tidak terlihat dan hasilnya tidak bersifat kepemilikan siapa pun. Pengetian pelayanan di atas dari semua pendapat membicarakan bagaimana cara memberikan pelayanan tertentu dari pihak penyedia layanan kepada pihak yang dilayani dimana sifatnya tidak terlihat dan hasilnya dapat dirasakan dan tidak bersifat kepelimilikan siapa pun.

Menurut Gibson, dkk dalam Hutasoit (2011:61) mengatakan bahwa pelayanan adalah kegiatan yang dikehendaki konsumen atau klien, atau pekerjaan yang dilakukan untuk orang lain. Kotler dan Amstrong dalam Hutasoit (2011b:61) mengatakan, pelayanan adalah kegiatan atau manfaat yang ditawarkan oleh satu pihak kepada yang lain yang pada dasarnya tidak kasat mata dan tidak melibatkan kepemilikan.
Pelayanan timbul karena adanya budaya kepentingan di dalam masyarakat. Pelayanan bukanlah sasaran atau kegiatan melainkan merupakan suatu proses untuk mencapai sasaran tertentu yang telah ditetapkan (Batinggi, 2008:3).

Selaras dengan pendapat Soetopo dalam Napitupulu (2007:164) mendefinisikan pelayanan sebagai suatu usaha untuk membantu menyiapkan (mengurus) apa yang di perlukan orang lain. Dalam Kamus Besar Bahasa Indonesia (2007:505) dinyatakan "Pelayanan adalah perihal atau cara melayani, meladeni dan kemudahan yang diberikan sehubungan dengan jual beli barang dan jasa". Pengertian ini menunjukkan bahwa orientasi pelayanan secara implisit dalam bentuk adanya suatu kepentingan baik barang maupun jasa. Jasa/pelayanan merupakan suatu kinerja (performance), tidak berwujud dan lebih dapat dirasakan daripada dimiliki. Dari dari pendapat diatas pelayanan merupakan suatu kegiatan organisasi atau individu yang memiliki karakteristik jasa yang tidak di rasakan secara fisik tetapi berupaya untuk kepuasan dan permintaan pelanggan. Dan mampu menyiapkan 
keperluan para pelanggan sehingga Menurut Purwono

(2011:36) mencapai sasaran yang ditentukan. Sehingga berdasarkan uraian di atas dapat dikatakan pelayanan merupakan kegiatan utama pada orang yang bergerak di bidang jasa, baik itu orang yang bersifat komersial ataupun yang bersifat non komersial. Namun dalam pelaksanaannya terdapat perbedaan antara pelayanan yang dilakukan oleh orang yang bersifat komersial yang biasanya dikelola oleh pihak swasta dengan pelayanan yang dilaksanakan oleh organisasi non komersial yang biasanya adalah pemerintah.

Kegiatan pelayanan yang bersifat komersial melaksanakan kegiatan dengan berlandaskan mencari eletronik library merupakan perpustakaan yang menyimpan informasi dalam bentuk digital atau pemenuhan akan kebutuhan informasi dalam bentuk digital dari sumbersumber informasi dari luar (eksternal) untuk disebarluaskan kepada pengguna baik yang terdaftar sebagai pelanggan (patron) tertentu maupun komunitas pada umumnya.

Wahano (2006:45) mendefinisikan perpustakaan digital sebagai suatu perpustakaan yang menyimpan data baik itu buku (tulisan), gambar, suara dalam bentuk file elektronik dan mendistribusikannya dengan menggunakan protokol elektronik keuntungan, sedangkan kegiatan melalui jaringan komputer. Menurutnya, pelayanan yang bersifat non komersial kegiatannya lebih tertuju pada istilah perpustakaan digital memiliki pemberian layanan kepada masyarakat pengertian yang sama dengan perpustakaan elektronik (electronic (layanan publik atau umum) yang sifatnya tidak mencari keuntungan akan library) dan perpustakaan maya (virtual library). Perpustakaan itu akan memiliki tetapi berorientasikan kepada banyak pengunjung apabila didukung pengabdian. prima, memuaskan, dan oleh kualitas pelayanan yang baik dan bermutu. Secara umum pelayanan memberikan rasa nyaman, senang, dan bermakna sebagai cara melayani, puas yang dirasakan oleh para pengguna membantu, menyiapkan, mengurus, jasa pelayanan perpustakaan tersebut, menyelesaikan keperluan, kebutuhan untuk itu perlu kita mengetahui lebih seseorang atau kelompok. jauh kajian tentang kualitas pelayanan. 
Pelayanan merupakan terjemahan dari istillah service dalam bahasa Inggris yang menurut Kotler yang dikutip Tjiptono, yaitu berarti "setiap tindakan atau perbuatan yang dapat ditawarkan oleh satu pihak ke pihak yang lain, yang pada dasarnya bersifat intangible (tidak berwujud fisik) dan tidak menghasilkan kepemilikan sesuatu

Dari beberapa kesimpulan diatas dapat ditarik garis tengah, bahwa eletronik library itu adalah sebuah perpustakaan yang menyediakan kemudahan akses bagi penggunanya yang didalamnya memiliki sumberdaya staf ahli, yang mempunyai berbagai macam model koleksi informasi, diantaranya dalam format file digital, yang dapat diakses dari jarak jauh dengan menggunakan jaringan internet. perpustakaan yang menggunakan jaringan internet serta perangkat

hardware dan software dalam pengalikasiannya.

\section{METODE PENELITIAN}

Penelitian ini dilaksanakan setelah proposal penelitian dalam rentang waktu dua bulan yaitu antara bulan april-juni 2016. Jenis penelitian bersifat deskriptif kuantitatif. Tipe penelitian yang digunakan dalam penelitian ini adalah survey yang dimaksudkan untuk melakukan pengamatan kritis pada obyek yang diteliti. Populasi adalah keseluruhan objek penelitian. Jadi dalam suatu penelitian, populasi harus ditentukan terlebih dahulu karena sebagai dasar untuk menentukan sampel. Berdasarkan pengertian maka yang menjadi populasi adalah seluruh mahasiswa. Populasi dalam penelitian ini adalah mahasiswa pengunjung di bulan april dan juni sebanyak 1000 orang pengunjung pada tahun 2016. Sampel adalah sebagian dari jumlah dan karakteristik yang dimiliki oleh populasi tersebut mengambil sampel 100 responden dengan tingkat kesalahan $10 \%$. Pengambilan sampel ini berdasarkan pada hasil perhitungan nrumus $=$ Slovin $\quad($ Sevilla,1993:161) yaitu :

$$
\frac{N}{1+N^{2}} \text { Adapun teknik sampel yang }
$$

diambil ditentukan dengan insidental sampling diambil secara kebetulan dimana seluruh pengunjung E-Library sampling yang ditemui pada saat pengambilan sampel berpeluang menjadi responden. atau siapa saja yang bertemu dengan peneliti dapat dijadikan sebagai responden. 
Dalam penelitian ini, Menunjukkan kebanyakan umur pengumpulan data dilakukan melalui responden berada pada kisaran umur beberapa teknik yang digunakan untuk 18s/d 19 tahun sebesar 42\%, yang umur memperoleh data-data dilapangan antara 20/22 sebesar $30 \%$, sedangkan terkecil lain; Kuesioner, Observasi, Dokumentasi.

\section{HASIL DAN PEMBAHASAN}

Berdasarkan dengan tujuan penelitian ini tercantum pada bab sebelumnya untuk mengetahui pelyanan akademik e-library Di Universitas Muhammadiyah Makassar, Kuesioner yang disebarkan dalam penelitian ini berjumlah 100 kuesioner dengan subjek penelitian mahasiswa. Berikut ini akan dipaparkan karakteristik responden secara umum menurut jenis kelamin,

umur dan jurusan. Berdasar karakteristik responden jenis kelamin adapun data yang di himpun dari hasil penelitian menunjukan bahwa 100 responden merupakan adalah jenis kelamin perempuan sebesar 80 perempuan sedangkan laki-laki sebanyak 20 orang itu tandanya bahwa perempuan lebih sering berkunjung dari pada laki-laki

Berdasarkan karakteristik tingkat umur. Adapun data yang di himpun dilihat dari 100 responden berada pada umur 23/24 tahun keatas yaitu sebesar $28 \%$. Ketiga karekteristik berdasarkan jurusan.

Selain iti berdasarkan tingkat jurusan responden dapat di himpun bahwa yang paling terendah adalah jurusan, Pai sebanyak 15 (15\%) orang, Adn sebanyak 14 (14\%) responden, Manajemen sebanyak 11 (11\%) orang, Matematika sebanyak 11 (11\%) orang, Pgsd sebanyak 12 (6.25\%) orang, begitu jurusan Bhs Inggris 22 (22\%) orang. Jika dilihat dari tabel diatas sebagian besar responden yang sering berkunjung di E-library adalah jurusan bahasa inggris dan Nampak bahwa responden didominasi jurusan Bahasa Inggris. Untuk mengetahui kualitas layanan akademik E-Library Universitas Muhammadiyah Makassar, penulis memilih 5 dimensi pelayanan publik yaitu 1. Keandalan (Reabilitiy), 2. Daya Tanggap (Responsiviness), 3. Keyakinan (Assurance), 4. Emphaty (Emphaty), 5. Berwujud (Tangbles), selain itu untuk mengetahui kualitas pelayanan publik juga menjadi hal yang penting. Besarnya 
kualitas pelayanan publik terhadap pelayanan. Maka dapat disimpulkan masing-masing indikator ditetapkan bahwa pelayanan akademik e-library dalam bentuk persentase dari jawaban memberikan pelayanan sesuai jasa yang di berikan dari tiap-tiap indikator berikut ini :

\section{Berdasarkan Tanggapan} dijanjikan sudah baik, baik dari tepat waktu dalam melayani mahasiswa responden tentang Reability dapat di lihat dari pelayanan akademik Universitas Muhammadiyah Makassar dapat dikatakan sangat baik berdasarkan tanggapan responden terhadap tiga indikator keandalan dalam memberikan sudah baik. Maupun ke nyataannya dengan hasil opservasi penulis me lihat bahwa kiner ja para pegawai sudah sangat baik. karena dilihat dari pendidikan yang dimiliki kemudian keahlian serta keterampilan memberikan pelayan yang memuaskan.

Tabel 10 : Rekapitulasi Tanggapan Responden Mengenai Keandalan (Reability) Pelayanan Akademik E-Library Di Unismuh

\begin{tabular}{|c|l|c|c|}
\cline { 1 - 2 } No & \multicolumn{1}{|c|}{ Tanggapan Responden } & $\begin{array}{c}\text { Rata-rata } \\
\text { Skor }\end{array}$ & $\begin{array}{c}\text { Rata-Rata } \\
\text { Persentase \% } \\
84\end{array}$ \\
\hline 1 & Jasa yang di janjikan & 3,36 & 3,60 \\
92 & Pelayanan cepat dan konsisten & 3,63 & 90,75 \\
\hline 3 & Pelayanan cepat dan terpercaya & $\mathbf{3 , 5 3}$ & $\mathbf{8 8 , 2 5}$ \\
\hline
\end{tabular}

Sumber : Diolah dari data primer, Juni 2016

Dari data di atas yang memberikan pelayanan cepat dan merupakan rekapitulasi dari ketiga terpercaya mendapat nilai yang indikator yang telah dipaparkan dapat diketahui bahwa kualitas pelayanan paling baik yaitu 2,96. Hal ini publik jika dilihat dari dimensi (reability) maka dapat dikatakan baik (berkualitas). Hal ini dapat dilihat dikarenakan dalam pembuatan kartu anggota perpustakaan sudah mengalami kemajuan dan soal memberikan pelayanan sesuai jasa dari rata-rata persentase rekapitulasi yang dijanjikan di nilai sudah baik sebesar $88,25 \%$. Kemampuan yaitu 2,82\%. 
Tabel 13 : Rekapitulasi Tanggapan Responden Mengenai Daya Tanggap (responsiveness)

dalam

Unismuh.

\begin{tabular}{|c|l|c|c|}
\hline No & \multicolumn{1}{|c|}{ Tanggapan Responden } & $\begin{array}{c}\text { Rata-rata } \\
\text { skor }\end{array}$ & $\begin{array}{c}\text { Rata-rata } \\
\text { Persentase }\end{array}$ \\
\hline 1 & Tanggap & 3,08 & 77 \\
\hline 2 & Cepat & 3,18 & 79,5 \\
\hline & Rata-rata dan Rata-rata Persentase & $\mathbf{3 , 1 3}$ & $\mathbf{7 8 , 2 5}$ \\
\hline
\end{tabular}

Sumber : Diolah dari data primer, Juni 2016

Dari data di atas yang bangunannya, penataan buku sudah merupakan rekapitulasi dari kedua cukup baik, dan para staf akademik indikator yang telah dipaparkan dapat tidak lagi cuek dalam melayani diketahui bahwa kualitas pelayanan mahasiswa. Harapan pelanggan pembuatan kartu anggota perpustakaan terhadap kecepatan pelayanan sudah jika dilihat dari ketanggapan terlaksana dengan baik akan tetapi (responsiveness) maka dapat dikatakan cenderung meningkat dan waktu ke sudah baik (berkualitas), hal ini dapat waktu.Perlu diingat bahwa keinginan dilihatdarirata-ratapersentase pelanggan padasatu waktu bisa rekapitulasi sebesar 3,13 (78.25\%.). dipersepsi berbeda antara satu Oleh karena itu Pelayanan yang pelanggan dan pelanggan lain. diberikan oleh staf/pegawai tergolong sangat cepat sekarang karena begitu banyak peningkatan setelah dirinovasi

Tabel 16 : Rekapitulasi Tanggapan Responden Mengenai Jaminan (Assurance) dalam Pelayanan Akademik E-library Di Unismuh.

\begin{tabular}{|c|l|c|c|}
\hline No & \multicolumn{1}{|c|}{ Tanggapan Responden } & $\begin{array}{c}\text { Rata-Rata } \\
\text { Skor }\end{array}$ & $\begin{array}{c}\text { Rata-Rata } \\
\text { Persentase }\end{array}$ \\
\hline 1. & Keterampilan & 3,19 & 79,75 \\
\hline 2. & Kesopanan & 3,34 & 83,5 \\
\hline 3 & $\begin{array}{l}\text { Kemampuan staf dalam menimbulkan } \\
\text { kepercayaan mahasiswa }\end{array}$ & 3,66 & 91,5 \\
\hline \multicolumn{2}{|l|}{ Rata-rata skor dan Rata-rata persentase } & $\mathbf{3 , 3 9}$ & $\mathbf{8 4 , 9 1}$ \\
\hline
\end{tabular}

Sumber : Diolah dari data primer, Juni 2016 
Berdasarkan data di atas amanah (kepercayaan) yang sudah merupakan rekapitulasi dari ke tiga tanggapan responden terhadap diberikan. Pelayanan akademik $e$ jaminan (Anssurance) dalam library harus memiliki keterampilan pelayanan akademik E-library Di

Unismuh Makassar berkategori sangat baik. Hal ini dapat dilihat dari Ratarata persentase rekapitulasi menunjukkan $3,39 \quad(84,91 \%)$. Itu tandanya para pegawai harus mampu menimbulkan kepercayaan terhadap pelayanan yang diberikannya kepada mahasiswa. Sehingga Seorang staf dalam pelayanan akademik harus bertanggung jawab atas pekerjaan atau yang dapat diartikan sebagai keahlian merujuk kepada kemampuan seorang pegawai untuk melakukan kegiatan atau tugas-tugas yang berkenaan dengan fisik dan mental tertentu. Keterampilan merupakan salah satu tolak ukur yang penting karena dengan keterampilan yang baik maka pegawai dapat menjalankan tugasnya dengan baik sehingga kualitas pelayanan juga dapat dinilai baik.

jabatan yang telah dipilih tersebut.

Tanggung jawab disini artinya, mau dan mampu menjaga

Tabel 19 : Rekapitulasi Tanggapan Responden Mengenai Perhatian (Empaty) dalam Pelayanan Akademik E-Library Di Unismuh

\begin{tabular}{|c|l|c|c|}
\hline No & Tanggapan Responden & $\begin{array}{l}\text { Rata-Rata } \\
\text { Skor }\end{array}$ & $\begin{array}{l}\text { Rata-Rata } \\
\text { Persentase }\end{array}$ \\
\hline 1. & $\begin{array}{l}\text { Memahami perhatian yang bersifat } \\
\text { individual atau kepada mahasiswa }\end{array}$ & $\mathbf{3 , 3 1}$ & $\mathbf{8 2 , 7 5}$ \\
\hline 2. & $\begin{array}{l}\text { Memahami keinginan atau kebutuhan } \\
\text { mahasiswa }\end{array}$ & $\mathbf{3 , 4 6}$ & $\mathbf{8 6 , 5}$ \\
\hline \multicolumn{2}{|l|}{ Rata-rata skor dan Rata-rata persentases } & $\mathbf{3 , 3 8}$ & $\mathbf{8 4 , 6 2}$ \\
\hline
\end{tabular}

Sumber : Diolah dari data primer, Juni 2016

Dari data diatas yang indikator yang telah dipaparkan dapat merupakan rekapitulasi dari kedua diketahui bahwa dalam pelayanan 
akademik e-library Di Unismuh berkategori sangat baik. Hal ini dapat dilihat dari rata-rata rekapitulasi

sebesar $\quad 3,38 \quad(84,62 \%)$ tidak diperdulikan. Empati merupakan sikap, respon dan tindakan dimana petugas dapat merasakan apa yang sedang dirasakan oleh mahasiswa. Dan kami para staf harus saling menegur ketika staf yang lainnya merasa kewalahan dalam melayani mahasiwa agar tercipta pelayanan prima dalam proses pelayanan akademik yang berikan kepada mahasiswa berjalan lancar sebagaimana mestinya. Tapi perpustakaan kampus UMM sebaiknya lebih banyak0 meningkatkan pelayanan agar kualitas pelayanan yang diberikan semakin baik, salah satu faktor elemen dasar kualitas pelayanan perpustakaan adalah kualitas meliputi usaha untuk memenuhi atau melebihi harapan atau segala sesuatu yang memuaskan pelanggan sesuai dengan persyaratan kebutuhan.

Kualitas pelayanan perpustakaan tergantung penuh kepada keterampilan dan profesionalisme. Para pemakai menyadari bahwa pemberi pelayanan dan para petugas memiliki pengetahuan dan ketrampilan yang diperlukan untuk memecahkan masalah secara profesional. Untuk terciptanya staf perpustakaan yang berkualitas diperlukan pengembangan sikap dan perilaku yang baik, sehingga akan dirasakan pengguna bahwa petugas pelayanan memperhatikan dan tertarik untuk memecahkan masalah pengguna secara spontan disamping dipersiapkan sistem akses kepada pelayanan sesuai dengan permintaan pelanggan.

Tabel 22 : Rekapitulasi Tanggapan Responden Mengenai Berwujud (Tangibles) Dalam Pelayanan Akademik E-Library Di Unimuh

\begin{tabular}{|c|c|c|c|}
\hline No & Tanggapan Responden & $\begin{array}{c}\text { Rata-Rata } \\
\text { Skor }\end{array}$ & $\begin{array}{c}\text { Rata-Rata } \\
\text { Persentase }\end{array}$ \\
\hline 1 & $\begin{array}{c}\text { Tersedianya fasilitas dan } \\
\text { perlengkapan }\end{array}$ & $\mathbf{2 , 3 6}$ & $\mathbf{5 9}$ \\
\hline $\begin{array}{c}2 \\
\text { menarik, sopan, ramah dan nyaman Rata- }\end{array}$ & $\begin{array}{c}\text { Penampilan para staf akademik yang } \\
\text { Rata dan Rata-Rata Persentase Sumber : }\end{array}$ & $\mathbf{3 , 5 9}$ & $\mathbf{2 , 9 8}$ \\
\hline
\end{tabular}

Diolah dari data primer, Juni 2016 
Dari data di atas yang merupakan rekapitulasi dari kedua indikator yang telah dipaparkan sebelumnya dapat diketahui bahwa kualitas pelayanan diperpustakaan

Universitas Muhammadiyah Makassar jika dilihat dari berwujud
(Tangibles) maka dapat dikatakan baik (berkualitas), hal ini dapat dilihat dari rata-rata persentase rekapitulasi sebesar 2,98 (74,37\%). Untuk melihat kesimpulan rata-rata

(\%) dari kelima dimensi pelayanan dapat dilihat pada tabel berikut ini.

\section{Tabel 23 : Rata-Rata Persentase Dari Kelima Indikator Pelayanan} Akademik Yang Berbasis E-Library Di Unismuh

\begin{tabular}{|c|l|c|c|c|}
\hline \multirow{2}{*}{ No } & Indikator Pelayanan & $\begin{array}{l}\text { Rata-Rata } \\
\text { Skor }\end{array}$ & $\begin{array}{l}\text { Rata-rata } \\
\text { Persentase }\end{array}$ & Kategori \\
\cline { 2 - 5 } & Keandalan (Reability) & 3,53 & 88,25 & Berkualitas \\
\hline 2 & $\begin{array}{l}\text { Ketanggapan } \\
\text { (Responsiveness) }\end{array}$ & 3,13 & 78,25 & Baik \\
\hline 3 & Jaminan (Assurane) & 3,39 & 84,91 & Berkualitas \\
\hline 4 & Emphty (Emphaty) & 3,38 & 84,62 & Berkualitas \\
\hline 5 & Berwujud (Tangibles) & 2,98 & 74,37 & Baik \\
\hline
\end{tabular}

Sumber : Diolah dari data primer, Juni 2016

Dari data diatas menunjukkan bahwa kualitas pelayanan Akademik Perpustakaan Universitas

Muhammadiyah Makassar khususnya dalam pelayanan pembuatan kartu anggota perpustakaan sudah berjalan baik (Berkualitas), hal ini dapat dilihat dengan rata-rata persentase penilaian responden pada kelima indikator pelayanan ini sudah berada di atas $60 \%$, maka untuk Keandalan (reability)

\section{3,53 dengan rata-rata presentase}

$(88,25 \%)$. Dengan demikian dapat disimpulkan bahwa kualitas pelayanan perpustakaan dilihat dari aspek keandalan sudah dikatakan baik. Hal ini sesuai dengan teori Philp Kotler dalam Supranto (2007:237) yang menjelaskan bahwa keandalan merupakan kepuasan pelanggan akan terpenuhi apabila kualitas produk /jasa yang diberikan sesuai dengan janjinya kepada pelanggan. Demi peningkatan kualitas layanan perlu adanya alas papan pengumuman untuk menjadi anggota Perpustakaan agar setiap masalah dapat teratasi dengan cepat sehingga tetap dapat mewujudkan pelayanan yang prima. 
Ketanggapan (Responsiveness)

3,13 dengan rata-rata responden $(78,25 \%)$ dikatakan baik karena kualitas pembuatan Kartu Elektrik Perpustakaan. Hal ini sesuai dengan apa yang diungkapkan dengan teori

Philip Kotler dalam Putranto (2007:237) yang menjelaskan bahwa ketanggapan akan memberikan pengaruh yang baik terhadap kepuasan pelanggan, karena tanggapan yang baik akan memberikan nilai kepuasan yang baik pula. Untuk meningkatkan kualitas pelayanan pembuatan Kartu Elektrik, perlu adanya perbaikan secara terus-menerus sehingga dapat menimbulkan kepuasan bagi pengguna jasa layanan perpustakaan.

\section{Jaminan (Assurance) 3,39} dengan rata-rata responden $(84,91 \%)$. Bahwa kualitas pelayanan akademik $e$ library dilihat dari aspek jaminan sudah dikatakan sangat baik. Hal ini sudah sesuai dengan apa yang diungkapkan teori Philip Kotler dalam Supranto (2007:237) yang menjelaskan bahwa jaminan terhadap kualitas pelayanan yang diberikan penyedia jasa maupun terhadap keamanan barang yang digunakan pelanggan.

Berdasarkan hasil rekapitulasi pelayanan akademik e-librarya sudah bisa memberikan pelayanan prima kepada pengguna perpustakaan. Tetapi perlu adanya perbaikan terutama mengenai keterampilan dan pengetahuan petugas dalam melakukan pelayanan sirkulasi ibarat jantungnya pusat pelayanan perpustakaan agar terwujudnya pelayanan prima yang bisa memuaskan pengguna perpustakaan.

$$
\text { Empati (emphaty) 3,38 }
$$

dengan rata-rata responden $(84,62 \%)$, bahwa kualitas pelayanan akademik $e$ library di Universitas Muhammadiyah Makassar dilihat dari aspek Empati sudah dikatakan sangat baik. hal ini sedah sesuai dengan apa yang diungkapkan dengan teori Philip Kotler dalam Supranto (2007:237) yang menjelaskan bahwa dengan Empati suatu pelayanan juga akan tercapai apabila timbul rasa nyaman yang dialami oleh pelanggan dalam menggunakan jasa pelayanan yang diberikan berdasarkan hasil rekapitulasi pelayanan perpustakaan sudah ada peningkatan dalam memahami keinginan mahasiswa dalam pelayanan peminjaman buku. Tetapi perlu adanya perbaikan demi 
peningkatan kualitas layanan dengan cara terbuka sehingga dapat mewujudkan pelayanan prima.

Sedangkan

Berwujud (tangibles) 2,36 dengan rata-rata responden $(74,37 \%)$. Bahwa dengan

kualitas pelayanan perpustakaan Universitas Muhammadiyah Makassar dilihat dari aspek tangibles sudah dikatanak cukup baik. Hal ini sudah sesuai dengan apa yang diungkapkan dengan teori Philip Kotler dalam Supranto (2007:237) yang menjelaskan bahwa dengan penampilan fasilitas fisik, peralatan personal media komunikasi berdasarkan hasil rekapitulasi pelayanan perpustakaan bahwa fasilitas masih sangat kurang terutama komputer, buku dan jaringan hostpotnya masih lambat ketika banyak pengunjung yang menggunakannya.

Tetapi perlu dibenahi guna meningkatkan kepuasan pengguna layanan jaringan.

\section{KESIMPULAN}

Berdasarkan hasil penelitian yang telah dibahas pada bab sebelumnya, maka dapat ditarik kesimpulan bahwa kualitas pelayanan publik pada perpustakaan Universitas
Muhammadiyah Makassar khususnya dalam pelayanan pembuatan Kartu Anggota elektrik Perpustakaan dapat dikatakan berkualitas. Yang dapat dilihat dari lima dimensi yang penulis gunakan untuk mngukur kualitas pelayanan, yaitu :a. keandalan

(Reability) pelayanan akademik Universitas Muhammadiyah Makassar dapat dikatakan sangat baik berdasarkan tanggapan responden terhadap tiga indikator keandalan memberikan pelayanan jasa dijanjikan dengan nilai rata-rata skor 3,36 (84\%) berkategori baik, pelayanan cepat dan konsisten dengan nilai rata-rata skor 3,60 (90\%) berkategori baik, dan pelayanan cepat dan terpercaya dengan nilai rata-rata skor 3,63 $(90,75 \%)$ pada kategori sangat baik. Dengan melihat ketiga indikator tersebut dapat disimpulkan bahwa nilai rata-rata persentase dari variabel keandalan adalah 3,53 (87,08\%) pada kategori sangat baik, b. ketanggapan (Responsiveness) dalam pelayanan akademik dikategorikan sangat baik berdasarkan tanggapan responden terhadap dua indikator ketanggapan dengan nilai rata-rata skor $3,13(78,25$ $\%$ ) pada kategori baik, c. jaminan 
(Assurance) dalam pelayanan akademik yang berbasis E-library dikategorikan sangat baik berdasarkan tanggapan responden terhadap tiga indikator jaminan dalam keterampilan nilai rata-rata skor $3,19(79,75 \%)$ pada kategori baik, kesopanan dengan nilai rata-rata skor $3,34 \quad(83,5 \%)$ pada kategori baik, dan sifat dipercaya yang memiliki staf akademik dengan nilai rata-rata persentase 3,66 (91,5\%) pada kategori sangat baik. Dengan melihat ketiga indikator tersebut dapat disimpulkan bahwa nilai rata-rata persentase dari variabel jaminan adalah $3,39(84,91 \%)$ pada kategori sangat baik, d. Empati (Emphaty) dalam pelayanan akademik berbasis E-library di Universitas Muhammadiyah Makassar berada pada kategori sangat baik berdasarkan tanggapan responden terhadap dua indikator Emphaty dalam yang bersifat individual atau pribadi kepada mahasiswa dengan nilai ratarata skor 3,31 $(82,75 \%)$ pada kategori sangat baik, Memahami keinginan atau kebutuhan mahasiswa dengan nilai rata-rata skor $3,46 \quad(86,5 \%)$ pada kategori sangat baik. Dengan melihat kedua indikator tersebut dapat disimpulkan bahwa nilai rata-rata persentase dari variabel Emphaty adalah 3,38 ( 84,62\%) pada kategori sangat baik. Dan e. berwujud (Tangibles) dalam pelayanan akademik E-library dikategorikan sangat baik berdasarkan tanggapan responden terhadap kedua indikator sangat baik berwujud bahwa tersedianya fasilitas dan perlengkapan dengan nilai rata-rata skor 2,36 (59\%) pada kategori sangat baik. Dengan melihat dua indikator tersebut dapat disimpulkan bahwa nilai rata-rata persentase dari variabel berwujud adalah 2,98 $(85,75 \%)$. pada kategori baik. Dengan demikian dapat disimpulkan bahwa pelayanan akademik yang berbasis E-library di Universitas Muhammadiyah Makassar dinilai sangat baik dan berkualitas.

\section{DAFTAR PUSTAKA}

Amin W T. (1993). "Manajemen, Suat u Pengantar". Jakarta : PT Rinek a Cipta.

Atep Adya Barata, Dasar-Dasar Pelayanan Prima, (Jakarta : PT Elex Media Komputindo, Cet. II, 2004), 10

Bafadal, Ibrahim. 2005. Pengelolaan Perpustakaan Sekolah. Jakarta, Bumi Aksara.

Batinggi, A \& Ahmad, B. (2008). Manajemen Pelayanan Umum. Jakarta,Universitas terbuka.

Hasibuan, Melayu.2007.Manajemen Sumber Daya Manusia, cetakan 
kesembilan, Jakarta, PT Bumi Aksara

Hutasoit, C.S.2011. Pelayanan Publik Teori Dan Aplikasi. Jakarta

Kotler, Philip dan Armstrong, Gary. 2002.'Prinsip-prinsip pemarasan Edisi 12" Jakarta,Erlangga.

Masri Singarimbun dan Sofian Efendi, 20013. Metode Penelitian Survei LP3ES. Jakarta

Moenir, 2008: 27, Manajemen Pelayanan Umum di Indonesia, Jakarta, Bumi Aksara.

Purwono, 2011. Dokumentasi. Yogyakarta, Graha Ilmu.

Romi, Satria.Wahano, 2006. Teknologi Informasi Untuk Perpustakaan Digital dan Sistem Perpustakaan Digital, Yogykarta, Edisi Kesatu Ekonisia 